LWSA

Local Wisdom, Social, and Arts

PAPER - OPEN ACCESS

\title{
Strategi Pengembangan Agribisnis Hortikultura di Wilayah Pedesaan
}

\author{
Author $\quad$ : Jef Rudiantho Saragih \\ DOI $\quad: 10.32734 /$ lwsa.v1i1.143 \\ Electronic ISSN : :2654-7058 \\ Print ISSN : :2654-7066
}

Volume 1 Issue 1 - 2018 TALENTA Conference Series: Local Wisdom, Social and Arts

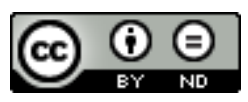

This work is licensed under a Creative Commons Attribution-NoDerivatives 4.0 International License.

Published under licence by TALENTA Publisher, Universitas Sumatera Utara
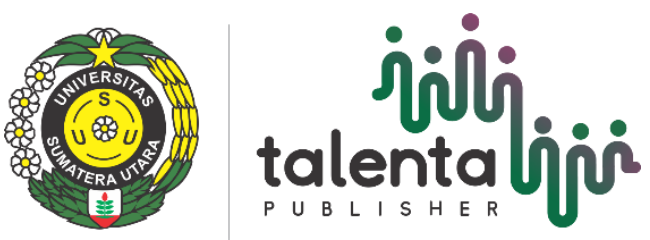


\title{
Strategi Pengembangan Agribisnis Hortikultura di Wilayah Pedesaan
}

\author{
Jef Rudiantho Saragih ${ }^{\mathrm{a}}$ \\ ${ }^{a}$ Fakultas Pertanian, Universitas Simalungun, Pematangsiantar-21139, Indoensia \\ jefsaragih@ymail.com
}

\begin{abstract}
Abstrak
Program-program pengembangan agribisnis di wilayah pedesaan masih menyisakan permasalahan mendasar yanitu harga sarana produksi pertanian terus meningkat, sementara harga produk pertanian primer sangat fluktuatif. Kondisi ini terjadi karena posisi tawar petani yang masih lemah di antara pelaku agribisnis lainnya. Penelitian bertujuan untuk mengukur kelayakan usahatani dan menemukan strategi pengembangan agribisnis hortikultura di Kabupaten Simalungun, Sumatera Utara. Dengan 40 rumah tangga sampel, kelayakan usahatani diukur dengan Revenue Cost Ratio (RCR) dan strategi pengembangan ditentukan melalui Analisis SWOT. Urutan kelayakan komoditas adalah kentang, cabai merah, kubis, tomat, dan jeruk manis. Hasil analisis SWOT untuk pengembangan agribisnis hortikultura mengutamakan strategi W-O yaitu mengubah strategi melalui: kemitraan pemasaran, pengembangan sumber air di usahatani, peningkatan kualitas jalan desa dan jalan usahatani, pengembangan kios sarana produksi di perdesaan, peningkatan penyuluhan pertanian, penataan zonasi dan pola tanam komoditas unggulan, pengembangan agroindustri skala rumah tangga dan skala kecil di perdesaan, serta pengembangan fasilitas kebun bibit dan lahan demplot
\end{abstract}

Kata kunci: Agribisnis; Hortikultura; RCR; Analisis SWOT

\section{Pendahuluan}

Pembangunan pertanian memegang peran yang strategis dalam perekonomian nasional, antara lain melalui kontribusi nyata dalam pembentukan kapital, penyediaan bahan pangan, bahan baku industri, pakan dan bio-energi, penyerap tenaga kerja, sumber devisa negara, dan sumber pendapatan, serta pelestarian lingkungan melalui praktik usahatani ramah lingkungan. [10].

Pengembangan agribisnis masih menghadapi berbagai kendala: tingginya harga sarana produksidan fluktuasi yang tinggi pada harga produk pertanian primer. Kondisi ini terjadi karena lemahnya posisi tawar petani dibandingkan dengan pelaku agribisnis lainnya. Selain itu [9], keterpaduan antarpemangku kepentingan juga menjadi kendala yang berarti. Di tingkat lokal, pengembangan agribisnis terutama terhambat akibat kendala infrastruktur wilayah yang sangat terbatas, seperti infrastruktur jalan dan fasilitas pendukung lainnya [11]. Di tingkat usahatani, kendala yang dihadapi petani adalah kuantitas, kualitas, dan kontinuitas sarana produksi pertanian dan hasil panen [9]; [13], fluktuasi yang tinggi harga produk pertanian primer [1]; [8]; [2], masalah kekeringan, dan lemahnya kelembagaan dan organisasi petani [18].

Berdasarkan kendala tersebut berbagai penelitian menawarkan solusi untuk pengembangan agribisnis hortikultura, yaitu penyempurnaan modelkelembagaan kemitraan agribisnis hortikultura agar efisien dan memiliki daya saing 
tinggi [13]; [14]; [7]; penguatan kelembagaan kelompok tani [18]; ketersediaan sarana pertanian, diversifikasi, dan pengaturan pola tanam sesuai permintaan pasar [11].

\section{Metode penelitian}

Penelitian dilaksanakan di Kabupaten Simalungun, Sumatera Utara. Lokasi penelitian berada di dua nagori (desa): Nagori Sinar Baru Kecamatan Silimakuta dan Nagori Bandar Sauhur Kecamatan Purba. Lokasi penelitian dipilih dengan metode sengaja dengan tujuan tertentu (purposive sampling) dimana dua desa merupakan lokasi pilot project Program Pengembangan Kawasan Perdesaan Berkelanjutan (P2KPB) Ditjen Penataan Ruang Kementerian PU tahun 2014. Kegiatan ini dilakukan melalui bekerjasama dengan Bappeda Simalungun. Tujuan awal proyek adalah merancang kebutuhan program kawasan untuk pengembangan agribisnis hortilkultura yang berkelanjutan. Sumbangan penelitian ini adalah untuk menganalisis kelayakan produk unggulan serta menemukan strategi dan program yang dibutuhkan untuk mewujudkan pengembangan agribisnis hortikultura yang berkelanjutan.

Kelayakan pengembangan produk unggulan ditentukan berdasarkan Revenue-Cost Rasio (RCR) dengan memilih 40 rumah tangga petani hortikultura, masing-masing 20 petani di setiap desa. Pemilihan petani dilakukan dengan metode acak sederhana (simple random sampling) dengan kerangka sampel (sample frame) yang didasarkan pada daftar anggota kelompok tani. Analisis RCR merujuk pada Syahza (2003) dan Hapsari et al. (2008). Untuk menemukan strategi dan program pengembangan agribisnis hortikultura dilakukan dengan Analisis SWOT. Data dan informasi mengenai kekuatan, kelemahan, peluang, dan ancaman pengembangan agribisnis hortikultura dikompilasi melalui diskusi kelompok terfokus (FGD) dengan pengurus kelompok tani dan gabungan kelompok tani. Analisis SWOT merujuk pada Taufik (2012), Syahza (2003), dan Sarworini (2012). Pengumpulan data usahatani dan kegiatan FGD dilakukan pada bulan Juni sampai Juli 2015.

\section{Hasil penelitian dan pembahasan}

\subsection{Kelayakan usahatani}

Analisis usahatani dapat digunakan untuk melihat kelayakan dan efisiensi kegiatan usahatani di tingkat petani. Analisis ini menggambarkan penerimaan total petani dari usahataninya sekaligus menggambarkan biaya produksi selama satu musim tanam atau satu periode waktu tertentu. Analisis usahatani mencakup revenue per cost (RCR) dan harga break event point (BEP) untuk skala per hektar dan skala usahatani rumah tangga. Analisis usahatani dilakukan untuk lima komoditas: kentang, cabai merah, kubis, tomat, dan jeruk manis. Untuk skala usahatani per hektar tidak ada komoditas yang memiliki $\mathrm{RCR} \geq 2$. Komoditas kentang, cabai merah, dan kubis memiliki nilai RCR berada di antara 1 dan 2. Artinya, usahatani tersebut dapat memeroleh keuntungan namun belum layak atau belum menarik bagi petani sebagai komoditas andalan. Bahkan komoditas tomat dan jeruk manis memiliki RCR lebih kecil dari 1. Usahatani dua komoditas ini sejatinya mengalami kerugian, dimana penerimaan lebih kecil daripada biaya produksi (Tabel 1).

Skala usahatani hortikultura di lokasi petani umumnya berada di bawah satu hektar. Untuk itu, dilakukan analisis usahatani untuk skala usaha rumah tangga. Dengan skala usaha rumah tangga tersebut, umumnya cukup dikelola dengan menggunakan tenaga kerja keluarga. Untuk melihat kelayakan dan efisiensi usahatani, dilakukan perhitungan dengan dan tanpa memasukkan biaya tenaga kerja keluarga. Bila biaya tenaga kerja dimasukkan dalam perhitungan, maka hanya komoditas kentang yang dinilai layak dan menarik bagi petani sebagai komoditas andalan. Cabai merah dan kubis memiliki nilai RCR antara 1 dan 2. Bahkan, RCR komoditas tomat dan jeruk manis bernilai di bawah 1 . 
Tabel 1. Kelayakan usahatani berdsarakan RCR.

\begin{tabular}{|c|c|c|c|c|c|c|c|c|c|}
\hline \multirow[b]{3}{*}{ No } & \multirow[b]{3}{*}{ Komoditas } & \multicolumn{2}{|c|}{ Perhektar } & \multicolumn{4}{|c|}{ Skala usaha rumah tangga } & \multirow{3}{*}{$\begin{array}{l}\text { Harga } \\
\text { saat } \\
\text { survei } \\
(\mathrm{Rp} / \mathrm{kg})\end{array}$} & \multirow{3}{*}{$\begin{array}{l}\text { Prakiraan } \\
\text { harga } \\
\text { agar } \\
\mathrm{RCR}=2 \\
(\mathrm{rp} / \mathrm{kg})\end{array}$} \\
\hline & & \multirow[b]{2}{*}{ RCR } & \multirow[b]{2}{*}{$\begin{array}{l}\text { Harga } \\
\text { BEP } \\
(\mathrm{Rp})\end{array}$} & \multicolumn{2}{|c|}{$\begin{array}{l}\text { Dengan biaya tenaga } \\
\text { kerja }\end{array}$} & \multicolumn{2}{|c|}{$\begin{array}{l}\text { Tanpa biaya tenaga } \\
\text { kerja }\end{array}$} & & \\
\hline & & & & RCR & $\begin{array}{l}\text { Harga BEP } \\
(\mathrm{Rp})\end{array}$ & $\mathrm{RCR}$ & $\begin{array}{l}\text { Harga } \\
\text { BEP } \\
(r p)\end{array}$ & & \\
\hline 1 & Kentang & 1,82 & 1,921 & 2,08 & 1.550 & 2,88 & 1.250 & 4.000 & 2.110 \\
\hline 2 & Cabai merah & 1,53 & 3.259 & 1,62 & 3.087 & 2,16 & 2.318 & 5.000 & 7.000 \\
\hline 3 & Kubis & 1,08 & 740 & 1,28 & 627 & 1,84 & 434 & 800 & 1.500 \\
\hline 4 & Tomat & 0,84 & 1.197 & 0,90 & 1.109 & 2,18 & 459 & 1.000 & 2.500 \\
\hline 5 & Jeruk manus & 0,82 & 4.888 & 0,97 & 4.111 & 1,18 & 3.378 & 4.000 & 10.000 \\
\hline
\end{tabular}

Keterangan:

1. $\mathrm{RCR}$ merupakan ukuran kelayakan finansial usahatani $(\mathrm{R}=$ revenue $=$ penerimaan; $\mathrm{C}=$ cost $=$ biaya produksi $)$. $\mathrm{RCR}$ dihitung berdasarkan harga rata-rata yang berlaku saat penelitian.

2. Skala usaha rumah tangga cukup menggunakan tenaga kerja keluarga (tidak dihitung petani sebagai biaya)

3. Luas skala usaha rumah tangga: kentang 0,40 hektar; tomat 0,20 hektar; cabai merah 0,24 hentar; kubis0,20 hektar; dan jeruk manis 0,25 hektar.

4. Jeruk umur 4 tahun (perhitungan per tahun); tomat, cabai merah, dan kubis (perhitungan per musim tanam)

Selanjutnya, jika biaya tenaga kerja keluarga tidak diperhitungkan dalam analisis usahatani, tiga komoditas (kentang, cabai merah, dan tomat) menjadi layak dikembangkan dan menarik bagi petani sebagai komoditas andalan $(\mathrm{RCR} \geqslant 2)$, sementara komoditas kubis dan jeruk manis hanya memiliki RCR antara 1 dan 2 . Secara umum, nilai RCR yang diperoleh pada penelitian ini relatif lebih tinggi dari usahatani bawang merah di dua desa di Majalengka yaitu 1,10 dan 1,07 [2]. Sementara Darwis dan Muslim (2013) pada penelitiannya di Karawang menemukan RCR untuk tanaman mentimun, bawang merah, dan kacang panjang berturut-turut adalah 1,42; 1,77; dan 1,58.

\subsection{Strategi pengembangan agribisnis hortikultura}

Untuk menemukan strategi pengembangan agribisnis berbasis hortikultura, diidentifikasi kondisi saat ini terkait dengan berbagai kekuatan, kelemahan, peluang dan ancaman pengembangannya terutama di tingkat petani. Diskusi kelompok terfokus dilakukan untuk mengidentifikasi empat komponen a nalisis SWOT. Berdasarkan pentingnya aspek yang diidentifikasi, maka ditemukan berbagai kekuatan pengembangan agribisnis hortikultura, yaitu: (1) kondisi agroklimat dan lahan sangat mendukung, (2) pengetahuan dan keterampilan petani mengenai budidaya komoditas unggulan sudah relatif baik, (3) lokasi penelitian merupakan kawasan strategis kabupaten (KSK) pengembangan agribisnis, (4) ada kelembagaan petani berupa kelompok tani, gapoktan, dan koperasi, (5) peluang intensifikasi dan ekstensifikasi, (6) petani adaptif terhadap informasi dan teknologi baru, (7) lokasi usahatani berpotensi dikembangkan sebagai objek agrowisata, dan (8) komitmen pemerintah daerah untuk mengembangkan agribisnis.

Kelemahan pengembangan agribisnis hortikultura adalah: (1) ketersediaan, harga, dan kualitas sarana produksi pertanian belum terjamin, (2) risiko gagal panen akibat musim kemarau, (3) penggunaan pupuk kimia dan obatobatan pertanian tidak tepat, (4) produktivitas hortikultura masih relatif rendah, (5) perencanaan tanam belum baik dan pola produksi tersebar, (6) kualitas, kontinuitas, dan kuantitas produksi belum terjamin, (7) adopsi teknologi baru belum berdasarkan uji coba/demplot, (8) pemasaran hasil pertanian masih nirkemitraan, (9) belum tersedia pos pengumpul, sortasi, dan pengemasan hasil pertanian di tingkat desa, (10) belum ada introduksi industri kecil/rumah tangga untuk mengurangi risiko fluktuasi harga hasil pertanian, (11) akses jalan ke desa dan jalan usahatani belum memadai, dan (12) pelayanan penyuluhan masih sangat minim.

Faktor eksternal yang diidentifikasi sebagai peluang untuk meningkatkan pengembangan agribisnis hortikultura adalah: (1) lokasi penelitian merupakan sentra hortikultura yang penting di Sumatera Utara, bahkan di tingkat 
nasional, (2) permintaan produk hortikultura yang berkualitas (bersertifikat) meningkat terutama untuk pasar ekspor, (3) akses jalan dan pelabuhan ke pusat-pusat konsumen relatif lancar, (4) ada minat pemodal dari luar kabupaten untuk melakukan aktivitas agribisnis, (5) ada kecenderungan peningkatan permintaan akan wisata alam dan agrowisata, dan (6) ada peluang pemasaran langsung antarwilayah $(G$ to $G)$ dengan tumbuhnya pusat perbelanjaan di perkotaan.

Disamping berbagai peluang, ancaman pengembangan hortikultura adalah: (1) peningkatan produksi, kualitas, dan inovasi di sentra produksi hortikultura di wilayah lain menjadi pesaing untuk merebut konsumen produk sejenis, (2) klaim produk di mancanegara dan pencemaran lingkungan hidup akibat praktik usahatani konvensional, (3) fluktuasi harga yang tinggi menjadi risiko paling berat bagi petani, (4) intervensi gaya hidup, nilai, dan budaya luar, dan (5) pola kepemilikan lahan secara perlahan berubah akibat kepemilikan lahan guntai.

Dalam berbagai aspek yang telah diidentifikasi mengenai kekuatan, kelemahan, peluang, dan ancaman tersebut, dikaji dengan analisis SWOT untuk menemukan kondisi pengembangan saat ini. Untuk menemukan kondisi terkini mengenai pengembangan agribisnis hortikultura, maka dilakukan pemberian bobot (weight) dan peringkat (rating) untuk setiap aspek yang diidentifikasi pada empat komponen analisis SWOT. Hasil pemberian bobot untuk faktor internal dan eksternal, disajikan pada Tabel 2 dan Tabel 3.

Tabel 2. Bobot dan rating untuk factor internal (kekuatan dan kelemahan).

\begin{tabular}{|c|c|c|c|c|}
\hline & Kekuatan (Strenghts, $S$ ) & Bobot $(b)$ & Rating $(r)$ & $(b \times r)$ \\
\hline 1 & Kondisi agroklimat dan iklim & 0,10 & 5 & 0,50 \\
\hline 2 & Intensifikasi dan ekstensifikasi & 0,09 & 4 & 0,36 \\
\hline 3 & Kelembagaan petani: poktan, gapoktan, koperasi & 0,06 & 2 & 0,12 \\
\hline 4 & Pengetahuan dan keterampilan petani & 0,06 & 2 & 0,12 \\
\hline 5 & Lokasi merupakan KSK pengembangan agribisnis & 0,06 & 2 & 0,12 \\
\hline 6 & Petani adaptif terhadap informasi dan teknologi baru & 0,06 & 2 & 0,12 \\
\hline 7 & Komitmen pemerintah daerah & 0,06 & 2 & 0,12 \\
\hline \multirow[t]{3}{*}{8} & Potensi pengembangan agrowisata & 0,04 & 1 & 0,04 \\
\hline & Jumlah & 0,53 & -- & 1,50 \\
\hline & Kelemahan (Weaknesses, W) & & & \\
\hline 1 & Pemasaran hasil pertanian belum ada kemitraan & 0,08 & 5 & 0,4 \\
\hline 2 & Resiko gagal panen akibat musim kemarau & 0,07 & 4 & 0,28 \\
\hline 3 & Akses jalan ke nagori dan jalan usahatani & 0,07 & 4 & 0,28 \\
\hline 4 & Ketersediaan, harga, dan kualitas saran produksi & 0,07 & 3 & 0,21 \\
\hline 5 & Pelayanan penyuluhan masih sangat minim & 0,07 & 3 & 0,21 \\
\hline 6 & $\mathrm{~K} 3$ produksi belum terjamin & 0,05 & 3 & 0,15 \\
\hline 7 & Produktivitas pertanian masih relative rendah & 0,03 & 2 & 0,06 \\
\hline 8 & Adopsi teknologi baru belum hasil uji coba/demplot & 0,01 & 1 & 0,01 \\
\hline 9 & Belum ada pos pengumpul, sortasi, dan pengemasan & 0,01 & 1 & 0,01 \\
\hline \multirow[t]{2}{*}{10} & Belum ada introduksi industry kecil/rumah tangga & 0,01 & 1 & 0,01 \\
\hline & Jumlah & 0,47 & -- & 1,62 \\
\hline
\end{tabular}

Pada faktor internal, jumlah bobot dikali rating $(b \mathrm{x} r)$ untuk komponen Kekuatan adalah 1,50, sementara untuk komponen Kelemahan adalah 1,62. Selisih komponen Kekuatan dan Kelemahan adalah 0,50 dikurang 1,62 yaitu 0,12. Selisih perhitungan ini menjadi posisi titik pada sumbu X. Pada faktor eksternal, jumlah bobot dikali rating (b $\mathrm{x} r$ ) untuk komponen Peluang adalah 1,76, sementara untuk komponen Ancaman adalah 1,59. Selisih komponen Peluang dan komponen Ancaman adalah 1,76 dikurang 1,59 yaitu 0,17. Hasil selisih ini menjadi posisi titik pada sumbu Y. Posisi pada Gambar 1 berada pada kuadran II yang menandakan kondisi pengembangan agribisnis 
hortikultura saat ini yang masih lemah namun sangat berpeluang untuk ditingkatkan. Strategi yang diusulkan adalah Perubahan Strategi (Turn Around), artinya petani dan stakeholder agribisnis lainnya harus mengubah strategi yang ditempuh selama ini.

Tabel 3. Bobot dan rating untuk factor eksternal (peluang dan acaman).

\begin{tabular}{|c|c|c|c|c|}
\hline & Peluang (Opportunities, $\mathrm{O}$ ) & Bobot $(b)$ & Rating $(r)$ & $(b \times r)$ \\
\hline 1 & Permintaan ekspor produk hortikultura berkualitas & 0,14 & 5 & 0,70 \\
\hline 2 & Lokasi merupakan sentra hortikultura yang peting & 0,12 & 4 & 0,48 \\
\hline 3 & Akses ke pusat-pusat konsumen relative lancer & 0,10 & 3 & 0,30 \\
\hline 4 & $\begin{array}{l}\text { Pemasaran langsung antarwilayah dengan system } G \\
\text { to } G\end{array}$ & 0,08 & 2 & 0,16 \\
\hline 5 & $\begin{array}{l}\text { Minat pemodal dari luar kabupaten di bidang } \\
\text { agribisnis }\end{array}$ & 0,06 & 1 & 0,06 \\
\hline \multirow[t]{3}{*}{6} & Peningkatan permintaan wisata alam dan agrowisata & 0,06 & 1 & 0,06 \\
\hline & Jumlah & 0,56 & -- & 1,76 \\
\hline & Ancaman (Threats, $\mathrm{T})$ & & & \\
\hline 1 & K3 di wilayah lain mejadi pesaing & 0,13 & 5 & 0,65 \\
\hline 2 & Fluktuasi harga output yang tinggi & 0,12 & 4 & 0,48 \\
\hline 3 & $\begin{array}{l}\text { Klaim produk di mancanegara dari pertanian } \\
\text { konvensial }\end{array}$ & 0,09 & 3 & 0,36 \\
\hline 4 & Intervensi gaya hidup, nilai, dan budaya luar & 0,05 & 1 & 0,05 \\
\hline \multirow[t]{2}{*}{5} & Pola kepemilikan lahan guntai & 0,05 & 1 & 0,05 \\
\hline & Jumlah & 0,47 & -- & 1,59 \\
\hline
\end{tabular}

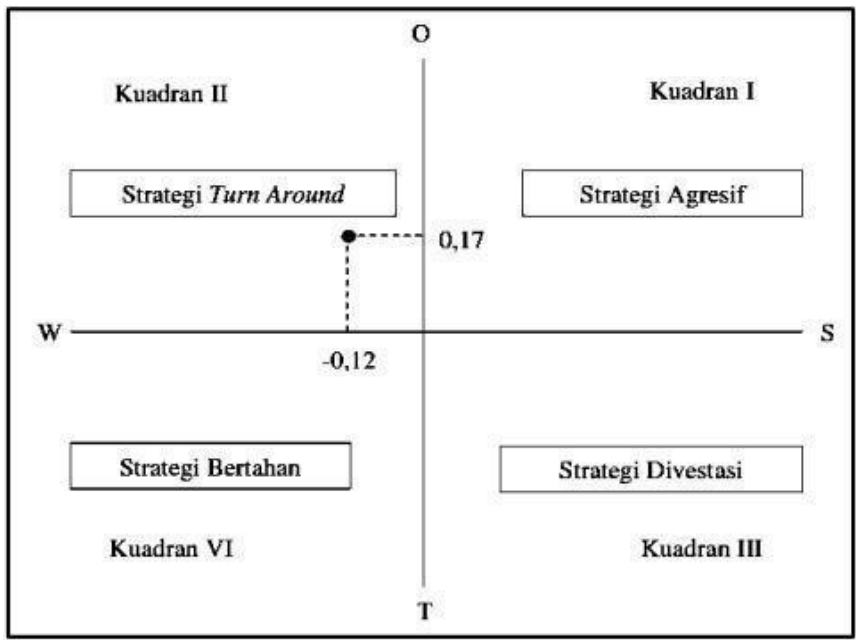

Gambar. 1. Posisi pengembangan agribisnis hortikultura.

Pengembangan agribisnis hortikultura memerlukan perubahan strategi dan program yang diperlukan berdasarkan tingkat kepentingannya. Perubahan strategi ditetapkan berdasarkan peringkat untuk keempat komponen SWOT. Strategi agresif (S-O) digunakan memaksimalkan kekuatan untuk meraih peluang secara optimal, strategi diversifikasi/ubah strategi (W-O) digunakan untuk meminimalkan kelemahan untuk meraih peluang semaksimal mungkin, strategi divestasi (S-T) digunakan memaksimalkan kekuatan untuk mengurangi ancaman yang ada, dan 
strategi bertahan (W-T) digunakan meminimalkan kelemahan dan hambatan untuk meminimalkan ancaman [11]. Strategi pengembangan disajikan pada Tabel 4.

Tabel 4. Matriks analisis SWOT pengembangan agribisnis hortikultura.

\begin{tabular}{|c|c|c|}
\hline \multirow[t]{6}{*}{$\mathrm{O}$} & $\begin{array}{l}\text { S } \\
\text { Strategi S-O }\end{array}$ & $\begin{array}{l}\text { W } \\
\text { Strategi W-O }\end{array}$ \\
\hline & $\begin{array}{l}\text { 1. Peningkatan produktivitas hortikultura melalui intensifikasi } \\
\text { dan ekstensifikasi. }\end{array}$ & 1. Pengembangan kemitraan pemasaran. \\
\hline & $\begin{array}{l}\text { 2. Penataan organisasi dan kelembagaan petani yang sudah } \\
\text { ada. }\end{array}$ & $\begin{array}{l}\text { 2. Pengembangan sumber air di lahan usuhatani secara } \\
\text { berkelanjutan. }\end{array}$ \\
\hline & $\begin{array}{l}\text { 4. Meningkatkan peran kelompok tani sebagai pelaku } \\
\text { produksi untuk menjamin keberlanjutan dalam kemitraan } \\
\text { pemasaran }\end{array}$ & $\begin{array}{l}\text { 4. Pengembangan kios sarana produksi di perdesaan oleh } \\
\text { kelembagaan petani }\end{array}$ \\
\hline & \multirow[t]{2}{*}{$\begin{array}{l}\text { 5. Peningkatan pengetahuan dan keterampilan petani dalam } \\
\text { wirausaha agrowisata. }\end{array}$} & $\begin{array}{l}\text { 5. Peningkatan layanan penyuluhan pertanian, termasuk } \\
\text { pembangunan pos penyuluhan desa. }\end{array}$ \\
\hline & & 8. Fasilitasi kebun bibit dan lahan demplot. \\
\hline \multirow[t]{4}{*}{$\mathrm{T}$} & Strategi S-T & Strategi W-T \\
\hline & $\begin{array}{l}\text { 1. Peningkatan kualitas produk hortikultura melalui pertanion } \\
\text { ramah lingkungan dan adopsi program sertifikasi produk. }\end{array}$ & 1. Pengembangan komoditas secara selectif dan dalam skala kecil. \\
\hline & $\begin{array}{l}\text { 2. Revitalisasi organisasi dan peran kelmbagaan petani untuk } \\
\text { memperkuat posisi tawar petani. }\end{array}$ & 2. Proteksi dan subsidi dari pemerintah \\
\hline & $\begin{array}{l}\text { 3. Perencanaan usahatani untuk meningkatkan pendapatan } \\
\text { petani dan keberlanjutan kepemilikan lahan. }\end{array}$ & 3. Menugtamakan hanya pasar-pasar local dan pasar tradisional. \\
\hline & & 4. Mengembangkan usaha lain di luar usahatani (off-farm) \\
\hline
\end{tabular}

Berdasarkan Tabel 4, strategi baru dalam pengembangan agribisnis hortikultura adalah mengutamakan Strategi W-O. Strategi ini diyakini dapat mendorong keberlanjutan pembangunan agribisnis hortikultura di wilayah perdesaan. Dari aspek ekonomi, meningkatkan pendapatan petani atau mengurangi kemiskinan; dari aspek sosial, strategi ini dapat diterima petani sekaligus mendorong peningkatan peran kelembagaan petani dalam pengembangan agribisnis; dan dari aspek ekologi, dapat mengurangi dampak negatif aktivitas agribisnis yang mencemari lingkungan hidup. Hermawan (2012) menyimpulkan bahwa sektor pertanian berperan penting dalam upaya pengurangan kemiskinan di wilayah perdesaan.

Strategi pengembangan yang direkomendasi adalah: (1) kemitraan agribisnis, (2) pengembangan sumber air di lahan usahatani, (3) peningkatan kualitas jalan akses ke desa dan pembangunan jalan usahatani/jalan kebun, (4) pengembangan kios sarana produksi pertanian di perdesaan yang dikelola oleh lembaga petani, (5) peningkatan layanan penyuluhan pertanian, (6) penataan zonasi dan pola tanam komoditas unggulan, (7) pengembangan agroindustri skala rumah tangga dan skala kecil, (8) pengembangan fasilitas kebun bibit dan lahan demplot, (9) pengembangan pos pengumpulan, sortasi, dan pengemasan produk pertanian di tingkat desa, (10) peningkatan kualitas produk hortikultura melalui intensifikasi dan ekstensifikasi melalui pertanian ramah lingkungan dan secara bertahap mengadopsi program sertifikasi produk, (11) revitalisasi organisasi dan peran kelembagaan petani, dan (12) peningkatan pengetahuan dan keterampilan petani dalam wirausaha agrowisata. 
Pentingnya kemitraan pemasaran disebabkan fluktuasi harga dan margin pemasaran yang tidak kondusif bagi pengembangan agribisnis dan peningkatan daya saing agribisnis [8]. Anugrah (2004) menyimpulkan permasalahan utama penanganan komoditas pertanian untuk meningkatkan kesejahteraan pelaku agribisnisnis terletak pada aspekaspek pemasaran hasil pertanian. Menurut Saptana et al. (2006), komoditas hortikultura memiliki keunggulan komparatif dan sekaligus keunggulankompetitif. Petani hortikultura membayar harga input produksi yang tinggi dan/atau menerima harga output yang rendah. Karena itu, srategi pengembangan kelembagaan kemitraan usaha agribisnis hortikulturamelalui proses sosial yang matang dengan dasar saling percaya di antara pelaku agribisnisdiharapkan dapat mewujudkan keunggulan bersaing.

Terkait dengan strategi pengembangan agribisnis hortikultura, hasil penelitian ini senada dengan Kasimin (2013). Variabel-variabel yang berperan positif dalam pengembangan agribisnis hortikultura (cabai merah, kentang, jeruk) adalah harga jual, biaya pemasaran, pola pembinaan, dansarana transportasi. Model pemberdayaan petani dapat merujuk pada Hasanuddin et al. (2009), yaitu peningkatan pengetahuan dan keterampilan petani, kemudahan permodalan, pembentukan lembaga pemasaran, pendampingan perubahan pola hidup dan sikap petani.

\section{Kesimpulan}

Urutan komoditas berdasarkan kelayakan pengembangan adalah kentang (dengan $\mathrm{R} / \mathrm{C}=1,82$ ), disusul cabai merah $(1,53)$, kubis $(1,08)$, tomat $(0,84)$, dan jeruk manis $(0,82)$. Usahatani menjadi lebih efisien jika dilakukan dengan skala usaha rumah tangga dengan $\mathrm{R} / \mathrm{C}=2,08$ (kentang), 1,62 (cabai merah), 1,28 (kubis), 0,97 (jeruk manis), dan 0,90 (tomat). Komoditas ini lebih efisien dalam skala usaha rumah tangga karena umumnya petani tidak menghitung biaya tenaga kerja keluarga dalam rasio penerimaan - biaya, yaitu: 2,88 (kentang), 2,16 (cabai merah), 2,18 (tomat), 1,84 (kubis), dan 1,18 (jeruk manis).

Pilihan strategi pengembangan agribisnis hortikultura di Kabupaten Simalungun adalah Perubahan Strategi. Strategi pengembangan agribisnis hortikultura yang direkomendasi mengutamakan strategi divestasi (W-O) yaitu meminimalkan kelemahan untuk meraih peluang melalui pengembangan kemitraan pemasaran, pengembangan sumber air di lahan usahatani secara berkelanjutan, peningkatan kualitas jalan akses ke desa dan pembangunan jalan usahatani secara bertahap, pengembangan kios sarana produksi pertanian di perdesaan, peningkatan layanan penyuluhan pertanian, penataan zonasi dan pola tanam komoditas unggulan, pengembangan agroindustri skala rumah tangga dan skala kecildi perdesaan, dan pengembangan fasilitas kebun bibit dan lahan demplot.

Sementara strategi agresif (S-O) dengan peningkatan produktivitas melalui intensifikasi dan ekstensifikasi, penataan dan pemberdayaan kelembagaan petani, peningkatan peran kelompok tani, dan peningkatan pengetahuan dan keterampilan petani dalam wirausaha agrowisata. Strategi diversifikasi (S-T) melalui peningkatan kualitas produk hortikultura dengan metode pertanian ramah lingkungan dan secara bertahap mengadopsi program sertifikasi produk, revitalisasi koperasi simpan pinjam untuk memperkuat posisi tawar dalam kemitraan pemasaran. Strategi bertahan (W-T) melalui pengembangan komoditas secara selektif dan dalam skala kecil, mengutamakan hanya pasar-pasar lokal dan pasar tradisional, dan mengembangkan usaha lain di luar usahatani (off-farm).

\section{References}

[1] Anugrah, I. S. (2004). Pengembangan Sub Terminal Agribisnis (STA) dan pasar lelang komoditas pertanian dan permasalahannnya. Forum Penelitian Agro Ekonomi22 (2), 102-112.

[2] Basuki, R.S. (2014). Identifikasi permasalahan dan analisis usahatani bawang merah di dataran tinggi pada musim hujan di Kabupaten Majalengka. Jurnal Hortikultura24 (3), 266-275.

[3] Darwis, V. dan Muslim, C. (2013). Keragaman dan titik impas usahatani aneka sayuran pada lahan sawah di Kabupaten Karawang, Jawa Barat. SEPA9 (2), 155-162.

[4] Hapsari, H., Djuwendah, E., Karyani, T. (2008). Peningkatan nilai tambah dan strategi pengembangan usaha pengolahan salak Manonjaya. Jurnal Agrikultura 9 (3), 208-214.

[5] Hasanuddin, T., Trully, D., dan Endaryanto, T. (2009). Akar penyebab kemiskinan petani hortikultura di Kabupaten Tanggamus, Propinsi Lampung. Jurnal Agrikultura20 (3), 164-170.

[6] Hermawan, I. (2012). Analisis eksistensi sektor pertanian terhadap pengurangankemiskinan di pedesaan dan perkotaan. MIMBAR: Jurnal Sosial dan Pembangunan28 (2), 135-144.

[7] Indraningsih, K. S., Ashari, dan Friyatno, S. (2008). Strategi pengembangan model kelemb agaan kemitraan agribisnis hortikultura di Bali. Pusat Analisis Sosial Ekonomi dan Kebijakan Pertanian, Departemen Pertanian. 
[8] Irawan, B. (2007). Fluktuasi harga, transmisi harga, dan marjin pemasaran sayuran dan buah. Analisis Kebijakan Pertanian5 (4), $358-373$.

[9] Kasimin, S. (2013).Keterkaitan produk dan pelaku dalam pengembangan agribisnis hortikultura unggulan di Provinsi Aceh. Jurnal Manajemen \& Agribisnis10 (2), 117-127.

[10] Kementerian Pertanian RI. (2011). Rencana Strategis (Renstra) Kementerian Pertanian 2010-2014, Edisi Revisi.

[11] Taufik, M. (2012). Strategi pengembangan agribisnis sayuran di Sulawesi Selatan. Jurnal Litbang Pertanian31 (2), $43-50$.

[12] Saptana, Saktyanu K.D., Wahyuni, S., Ariningsih, E., dan Darwis, V. (2004). Integrasi kelembagaan Forum KASS dan program agropolitan dalam rangka pengembangan agribisnis sayuran Sumatera. Analisis Kebijakan Pertanian2 (3), 257-276.

[13] Saptana, Sunarsih, dan Indraningsih, K.S. (2006a). Mewujudkan keunggulan komparatif menjadi keunggulan kompetitif melalui pengembangan kemitraan usaha hortikultura. Forum Penelitian Agro Ekonomi24 (1), 61-76.

[14] Saptana, Hastuti, E.L., Indraningsih, K.S., Ashari, Friyatno, S., Sunarsih, Darwis, V. (2006b).

[15] Pengembangan kelembagaan kemitraan usaha hortikultura di Sumatera Utara, Jawa Barat, dan Bali. Pusat Analisis Sosial Ekonomi dan Kebijakan Pertanian, Departemen Pertanian.

[16] Sarworini. (2012). Arah dan strategi pengembangan agribisnis hortikultura di Kawasan Agropolitan Kabupaten Pemalang. Program Studi Magister Agribisnis, Program Pascasarjana Universitas Diponegoro.

[17] Syahza, A.(2003). Analisis ekonomi usahatani hortikultura sebagai komoditas unggulan agribisnis di daerah Kabupaten Pelalawan Propinsi Riau.

[18] Zakaria, W. A. (2008). Penguatan kelembagaan kelompok tani kunci kesejahteraan petani. Pusat Analisis Sosial Ekonomi dan Kebijakan Pertanian. 